\title{
The influence of shale gas mining activities on the natural environment in Poland
}

\author{
Justyna Pyssa ${ }^{1, *}$ \\ ${ }^{1}$ AGH University of Science and Technology, Faculty of Energy and Fuel, Al. Mickiewicza 30, 30-059 Cracow, Poland
}

\begin{abstract}
In the paper the main threats to the environment arising from works related to the exploration of gas from unconventional sources have been discussed. The influence of exploration works on the atmosphere (the emission of gases to the atmosphere as a result of fuel combustion, the emission of noise by drilling equipment) has been explained. Threats to the hydrological balance associated with the intake of water for performing the process of fracturing have been discussed. Legal regulations connected with waste management, water resource management and protected areas (Nature 2000) have been presented.
\end{abstract}

\section{Introduction}

The exploration for shale gas in Poland has been lasting for seven years now. The locations of Polish gas fields range from the middle-east coast of the Baltic sea through the central part of Poland to the Lubelskie region (the Lublin basin). Additionally, four boreholes were drilled in the south-west part of Poland (in the Silesian Lowland and the Opole region) [1].

All stages of works connected with the exploration and extraction of hydrocarbons from unconventional sources affect the natural environment.

The consequence of exploitation is taking large pieces of land for the need of a drill site along with necessary infrastructure.

The extent to which drilling works influence particular components of the environment depends on many factors. The most important are the degree of urbanization of the area, sensitivity of individual elements of the environment to pollution, type of drilling equipment, depth of boreholes, sort of drilled rocks, and type and scope of works stimulating the inflow of hydrocarbons to the hole.

\section{Concessions and area of exploration in Poland}

The possibility of exploitation of energy raw materials from new sources always raises expectations especially in the area of economic advantages. As of the $28^{\text {th }}$ of February 2017, the number of concessions for the exploration and prospection of shale gas deposits in Poland amounted to 20 [2].

Until the $28^{\text {th }}$ of February $2017-27$ exploration boreholes were drilled in Poland, 54 of which are vertical holes and 18 bent-horizontal ones [2]. In a part of boreholes special treatments were conducted -28 procedures of fracturing and 9 measures of micro- fracturing (DFIT - Diagnostic Fracture Injection Test). In Table 1 a summary of drilled holes along with applied treatments in the years 2010-2016 is presented.

Table 1. Summary of drilled exploratory boreholes for shale gas along with the type of applied special treatments (data as of the 28th of Feb 2017) [author's own research based on 2]

\begin{tabular}{|c|c|c|c|}
\hline \multirow[t]{2}{*}{ Year } & \multirow{2}{*}{$\begin{array}{l}\text { Number } \\
\text { of } \\
\text { boreholes }\end{array}$} & \multicolumn{2}{|c|}{$\begin{array}{l}\text { Type of treatments conducted in } \\
\text { borehole }\end{array}$} \\
\hline & & Fracturing & $\begin{array}{c}\text { Micro- } \\
\text { fracturing/ } \\
\text { Diagnostic } \\
\text { Fracture } \\
\text { Injection Test } \\
\text { (DFIT) }\end{array}$ \\
\hline 2010 & 3 & 2 & 1 \\
\hline 2011 & 12 & 7 & 0 \\
\hline 2012 & 24 & 8 & 7 \\
\hline 2013 & 14 & 4 & 1 \\
\hline 2014 & 15 & 5 & 0 \\
\hline 2015 & 4 & 0 & 0 \\
\hline 2016 & 0 & 2 & 0 \\
\hline
\end{tabular}

Locations of Polish deposits range from the middleeast Baltic coast through central Poland to the Lubelskie region [3].

One can distinguish three basins geologically and these are: baltic, podlaskie and lubelskie. Moreover, 4 boreholes were drilled in south-west part of Poland (in Silesian Lowlands and Opolskie region) [1].

In Fig. 1 areas of exploration for shale gas are presented (as of the $30^{\text {th }}$ of April 2016). Areas in which concessions for the natural shale gas exploration apply are marked in red, while areas for which requests for the exploration of natural shale gas have been submitted are marked in pink.

\footnotetext{
* Corresponding author: jpyssa@agh.edu.pl
} 


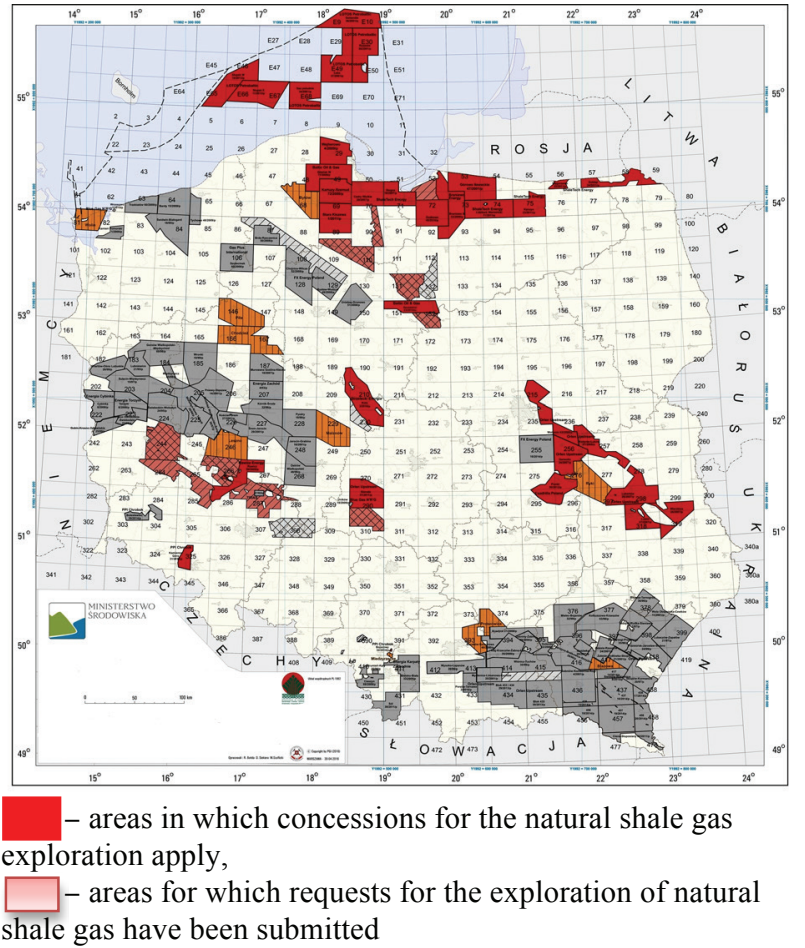

Fig. 1. Areas of exploration for shale gas [4].

\section{Environmental aspects of exploration and exploitation of shale gas deposits}

Particular phases of exploration and exploitation of shale gas deposits have an influence on the condition of natural environment. In case of failure to comply with procedures, human errors and random incidents, the pollution of water (surface and ground) and the emission of contaminants to the air may occur. There is also a significant risk of adverse influence of performed work on the biodiversity and landscape around a drilling rig.

\subsection{Preparatory work}

The degradation of soil environment occurs most often during the preparatory and assembly work. They include activities connected with the preparation of access roads, area of drilling rig and also during laying foundations for technological equipment. The area intended for the drilling rig usually takes from one to several hectares [57]. Still, taking into account the fact that there can be several bore-holes and each one of them requires bringing access roads, the total extent of land surface requiring the reclamation later can be significant.

Within the scope of work connected with the preparation of area for exploitation one also performs sealing of sites intended for warehousing of fuels, materials for drilling fluid and surface system for drilling fluid cleaning with the aid of geo-membrane [6].

\subsection{Drilling work}

The degradation of soil and water environment most often occurs during warehousing and distribution of diesel oil, warehousing of materials for drilling fluid, compiling and cleaning of drilling fluid, temporary storage of sewage and drilling waste in the area of a rig as well as during preparation for and performing fracturing procedures [6]. Cleaning of drilling fluids takes place in the area of a drilling rig with the use of vibrating, linear and double-deck sieves, desanding equipment, desludgers, centrifuges, hydrocyclones, flocculating stations. Those measures enable the re-use of drilling fluid both for boring another hole and applying as groundwork for compiling a new drilling fluid [1].

During extraction work sometimes there may happen an emergency discharge of drilling fluid, brine, natural gas and hydrogen sulphide which accompanies them. Most of the time it is a result of human error, equipment failure, hard-to-predict deposit conditions [6].

\subsection{Noise emission}

The main sources of noise in the area of drilling rig are power generators, internal combustion engines of drilling equipment and drilling fluid pumps, the drilling fluid pumps and vibrating sieves [6]. Additionally, an important source of sound is the vehicle traffic connected with deliveries of materials and equipment [7]. The research conducted in Poland in the area of drilling rig [5] revealed that the activity of the drilling rig influenced the acoustic environment in the immediate vicinity of workshop. The key factor limiting the level of noise pollution is the distance between the location of workshop and residential areas. The averaged level of noise in the immediate vicinity of workshop amounted to $81 \mathrm{~dB}$, at a distance of 200 meters $-50.6 \mathrm{~dB}$, while at the distance of $500 \mathrm{~m}-37.9 \mathrm{~dB}$. The norm for farm building is $55 \mathrm{~dB}$ in a day and $45 \mathrm{~dB}$ at night.

\subsection{Pollution emission to atmosphere}

The exploration and production of shale gas may include a variety of potential air emission sources that change depending on the phase of operation. In the early phases of operation, emissions may come from such sources as drilling rigs whose engines may be fueled by either diesel or natural gas and from fracturing operations where multiple diesel-powered pumps are often used to achieve the necessary pressure $[8,9]$.

Other sources may include the well completion process, which may involve the venting or flaring of some natural gas, and vehicular traffic with engine exhaust and dust from unpaved roads [5, 8]. In Table 2 values of maximum concentrations emitted at particular stages of work in relation to the valid Polish legislation are presented.

As it arises from the data placed in Table 2 at all stages of conducting work related with the shale gas exploration in Poland no excess in the emission of $\mathrm{NO}_{2}$, benzene and BTEX was recorded. Among measured indicators of contamination, significant excesses were recorded in case of hydrocarbons $-\mathrm{C}_{2}$ to $\mathrm{C}_{12}$, especially in case of fracturing and reception of procedure fluid. 
Table 2. Values of maximum concentrations examined at particular stages of work in relation to the Polish legislation (author's own research based on $[5,10,11]$

\begin{tabular}{|l|c|c|c|c|c|c|c|}
\hline Indicator & $\begin{array}{c}\mathrm{SO}_{2} \\
{\left[\mu \mathrm{g} / \mathrm{m}^{3}\right]}\end{array}$ & $\begin{array}{c}\mathrm{NO}_{\mathrm{x}} \\
{\left[\mu \mathrm{g} / \mathrm{m}^{3}\right]}\end{array}$ & $\begin{array}{c}\text { Methane } \\
{\left[\mu \mathrm{g} / \mathrm{m}^{3}\right]}\end{array}$ & $\begin{array}{c}\text { Hydrocar-bons } \\
\mathrm{C}_{2}-\mathrm{C}_{12} \\
{\left[\mu \mathrm{g} / \mathrm{m}^{3}\right]}\end{array}$ & $\begin{array}{c}\mathrm{VOCs} \\
{\left[\mu \mathrm{g} / \mathrm{m}^{3}\right]}\end{array}$ & $\begin{array}{c}\text { Benzene } \\
{\left[\mu \mathrm{g} / \mathrm{m}^{3}\right]}\end{array}$ & $\begin{array}{c}\mathrm{BTEX} \\
{\left[\mu \mathrm{g} / \mathrm{m}^{3}\right]}\end{array}$ \\
\hline $\begin{array}{l}\text { Reference } \\
\text { value- averaged } \\
\text { per 1 hour [10] }\end{array}$ & 350 & 200 & $\mathrm{n} / \mathrm{a}$ & 3,000 & $\mathrm{n} / \mathrm{a}$ & 30 & 850 \\
\hline $\begin{array}{l}\text { Reference } \\
\text { value- averaged } \\
\text { per year [10] }\end{array}$ & 20 & 40 & $\mathrm{n} / \mathrm{a}$ & 1,000 & $\mathrm{n} / \mathrm{a}$ & $\mathrm{n} / \mathrm{a}$ & $\mathrm{n} / \mathrm{a}$ \\
\hline $\begin{array}{l}\text { Reference } \\
\text { value- averaged } \\
\text { per 1 hour [11] }\end{array}$ & 350 & $\mathrm{n} / \mathrm{a}$ & $\mathrm{n} / \mathrm{a}$ & $\mathrm{n} / \mathrm{a}$ & $\mathrm{n} / \mathrm{a}$ & 5 & $\mathrm{n} / \mathrm{a}$ \\
\hline $\begin{array}{l}\text { Reference value } \\
\text { averaged per } \\
\text { year [11] }\end{array}$ & 20 & 30 & $\mathrm{n} / \mathrm{a}$ & $\mathrm{n} / \mathrm{a}$ & & \\
\hline $\begin{array}{l}\text { Neutral state/ } \\
\text { current state }\end{array}$ & $\mathrm{n} / \mathrm{a}$ & 88,7 & $1,000-1,400$ & $2,800-3,500$ & $6,500-6,600$ & $<1$ & $\mathrm{n} / \mathrm{a}$ \\
\hline Drilling & $18-133$ & $24-47$ & $\mathrm{n} / \mathrm{a}$ & 3,920 & 32,714 & $<1$ & 635 \\
\hline Fracturing & $119-815$ & $62-105$ & $1,300-3,470$ & $2,900-8,544$ & $5,500-15,400$ & 3.2 & $33-485$ \\
\hline $\begin{array}{l}\text { Reception of } \\
\text { post-procedure } \\
\text { fluid }\end{array}$ & 196 & 119 & 10,108 & 7,620 & 11,177 & $<1$ & 23.5 \\
\hline
\end{tabular}

$\mathrm{n} / \mathrm{a}-$ not applicable

VOCs - volatile organic compounds

BTEX - benzene, toluene, ethylbenzene and total xylenes emissions

The level for $\mathrm{SO}_{2}$ was also exceeded to a large extent during the fracturing process. One should also pay attention to the emission of hydrocarbons at the reception of post-procedure fluid. In order to counteract the emission it is necessary to use gas separators and techniques of afterburning (when the concentration is too low for self-ignition).

\subsection{Pollution of ground and surface water}

The contamination of ground water and useful aquifer layers may occur during the leakage of chemical substances (included in the composition of fracturing liquid) to the ground surface and as a result of breakages and leaks of pipes - in case of incorrect cementing casing strings while drilling.

Nowadays a frequently examined problem is the potential influence of hydraulic fracturing on underground aquifer layers. The current research conducted in Poland does not indicate that crevices resulting from procedures of hydraulic fracturing can reach the zone of underground water [12].

In north Poland in Pomerania rock formations, which are drilled because of the exploration of shale gas, are located at a depth of 3,000-4,500 $\mathrm{m}$ below the earth surface and the range of crevices is contained within a perimeter of 100 to 200 meters vertically $[5,12]$. Aquifer layers lying at a depth of 100 to 300 meters are isolated from gas-bearing shales by a bundle of impenetrable sediments in a form of clays and marls stemming from Upper Silurian of a thickness of 2,000 - 3,000 m [12].
They are also isolated by a cover of locally present Zechstein evaporites (rock salt, calcium sulphate anhydrite) of a thickness of 280 to $500 \mathrm{~m}$ [5] and local Triassic clays and shales of a thickness of 200 meters [12]. Therefore the sealing of shale complexes in Pomerania, as well as tightness of fault zones, is unquestionable. On the basis of conducted research [5] no threat of migration of fracturing fluids and gas to the surface and the level of service water has been noted.

In the Lublin area there are fault zones of complex tectonic evolution which makes that sealing complexes do not maintain full continuity. The Upper Silurian complex is pointed as the main sealing [5] (Ludlow and Pridoli). It is situated above fractured complexes of Lower Silurian. In the Syczyn OU-2K hole the thickness of that complex is 857 meters and the location of bearing series is at $2,700 \mathrm{~m}$, while in the Zwierzyniec- 1 hole the thickness of Upper Silurian is $1,387 \mathrm{~m}$ at a depth of bearing series at 3,100 meters [5].

\subsection{Seismic hazard}

In Poland the seismic hazard is not present. The occurrence of seismic events has not been noted in areas covered by licenses for the shale gas exploration. The area of Pomerania is the calmest in Europe in terms of seismic activity. The minimum risk of occurrence of seismic tremors concerns the Lublin region as well [5].

\subsection{Waste arising during drilling}

Corresponding author: jpyssa@agh.edu.pl 
As a result of works connected with the exploration and recognition of deposits of natural gas from unconventional accumulations 2 sorts of waste are generated $[1,5,6,13]$ :

1. Waste connected with drilling works - so-called extractive and drilling waste. Here one can classify used drilling fluids, flow-back fluids, reservoir fluids and solid waste produced during the purification of flow-back fluid (the sludge from separators and reservoirs, flow-back proppant etc.),

2. Waste resulting from the functioning of drilling rig (plastics, packages, filters, sorbents, used oil and grease, communal waste, etc.)

The main sources of contaminants present in the drilling waste are chemicals used for compiling and regulation of parameters of technological drilling fluids, biocides, petroleum substances, corrosion inhibitors, chemicals used for completion of deposits and stimulation of inflow of hydrocarbons and reservoir fluids - which are most often brines and crude oil $[1,6]$

Each drilling fluid has an increased $\mathrm{pH}$ value, increased amounts of undissolved and dissolved solid substances (Total dissolves solids - TDS) [1, 14, 15], surfactants, chloride and sulphate ions and dissolved organic carbon (Total organic carbon - TOC). It also includes small amounts of petroleum-derived hydrocarbons $[1,15,16]$, heavy metals (such as: arsenic, cadmium, barium, chromium, copper, mercury, nickel, lead, antimony, selenium, zinc, tin, cobalt) $[1,14,15$, 17] and also trace amounts of radioactive substances which come from shale formations $[1,12,14]$.

Drill cuttings (output) are crumbled fragments of rocks existing in the geological profile of the hole (clays, sands, loam, sandstones, shales, limestones, marlstones, claystones and dolomites) which are contaminated with remains of the drilling fluid, dissolved salts and heavy metals and - in trace quantities - radioactive elements (such as uranium, thorium and their decay products radium and radon) $[1,12]$.

In Poland several types of drilling fluids are applied for drilling exploratory holes. The decision on the selection of sort of drilling fluid is taken after taking into consideration the geological, technical and reservoir conditions [1].

\subsection{Water intake}

One of important elements of the influence on environment is the intake of both surface and ground water used in the process of hydraulic fracturing. The water utilized in the procedure of hydraulic fracturing can be brought from available waterworks, rivers and lakes and nearby waste treatment plants [12]. The optimum solution in obtaining water for the procedure of hydraulic fracturing is the re-use of flow-back fluid [1].

The available resources of aquiferous formations in Poland amounts to 13,300 million $\mathrm{m}^{3} /$ year at an average consumption of $11 \%$ [12]. Locations of Polish shale gas deposits range from the middle-east Baltic coast through Mazovia to the east part of the Lubelskie region, which are areas of lower-than-average water consumption. In
Table 3 there is a comparison of volumes of groundwater resources along with the utilization rate in a given area, including testing grounds in Pomerania and the Lubelskie region.

\section{Legislation}

The extraction of shale gas in Poland requires taking into consideration both the European and domestic legislation as well as directions in which it may evolve. On the one hand it has to do with the care about the natural environment, on the other hand it is a concern about creating incentives to produce the gas from unconventional resources which would influence the country's energy security to a large extent.

Rules of law which have an effect on undertakings connected with the exploration and exploitation of shale gas are presented below. To the most important ones one can rate acts dealing with the potential contamination of ground water by chemicals, soil pollution, waste disposal, influence on the area and landscape and effects of gas emission.

\subsection{Water management}

Significant element of the influence on the environment is the utilization of ground and surface water for the need of technological processes - hydraulic fracturing in particular. It is necessary to explore in what way performed work can affect the condition of ground water resources available for management and if the work can cause a potential reduction in the availability of those resources for other users - especially the human population.

The Water Framework Directive - the European Parliament and Council directive 2000/60/WE of the $23^{\text {rd }}$ of October 2000 establishing the framework for community action in the area of water policy [23] and its implementation to the Polish legislation through provisions of the Water Law (Journal of Laws of 2016, item 352, 1250 and 1948) [24] constituted the necessity of assessment of the qualitative status of ground water and its chemical condition...performed within the frames of evaluation of the status of uniform bodies of ground water (JCWPd), according to the article $38.5 \mathrm{~b}$. The data is placed in Table 3, while on Fig. 2 the rate of utilization of ground water resources in Poland in February 2017 is presented. In the areas of shale gas exploration the light-blue colour dominates which appears to confirm that the rate of utilization of ground water resources available for management, so the ratio of actual ground water intake to resources, is less than 15 percent. It is only the area where two exploratory holes Lubocino and Gapowo (pomorskie voivodship) - are located that the colour of marking is green which means that the rate of utilization of ground water resources available for management is from $30-60 \%$.

The directive on ground water - European Parliament and Council Directive 2006/118/WE of the $12^{\text {th }}$ of December 2006 on protection of the ground water against pollution and status deterioration [25] - which 
Table 3. Volume of groundwater resources along with their utilization, data for the year 2012 [author's own research based on 18-22]

\begin{tabular}{|l|c|c|c|c|c|c|}
\hline $\begin{array}{l}\text { Uniform Bodies of } \\
\text { Ground Water } \\
\text { JCWPd) number }\end{array}$ & Unit & $11^{[18]}$ & $13^{[19]}$ & $19^{[20]}$ & $28^{[21]}$ & $90^{[22]}$ \\
\hline Testing ground & Lebień & $\begin{array}{c}\text { Lubocino, } \\
\text { Gapowo }\end{array}$ & Stare Miasto & Wysin & $\begin{array}{c}\text { Syczyn, } \\
\text { Zawada }\end{array}$ \\
\hline Area & $\left.\mathrm{km}^{2}\right)$ & $3,969.0$ & $2,856.0$ & $3,917.4$ & $4,057.4$ & $4,901.0$ \\
\hline $\begin{array}{l}\text { Resources available } \\
\text { for development } \\
\text { (ZDZP) }\end{array}$ & $\mathrm{m}^{3 / \text { day }}$ & $708,387.0$ & $384,261.0$ & $375,026.0$ & $423,733.0$ & $675,140.0$ \\
\hline Rate of resource use & $\%$ & 6.9 & 37.7 & 6.0 & & 8.4 \\
\hline
\end{tabular}

introduces the obligation of monitoring of ground and surface water and identification of potential sources of pollution. It determines standards of quality for ground water (appendix I) and threshold values for pollutant concentrations and indicators of contaminants (appendix II).

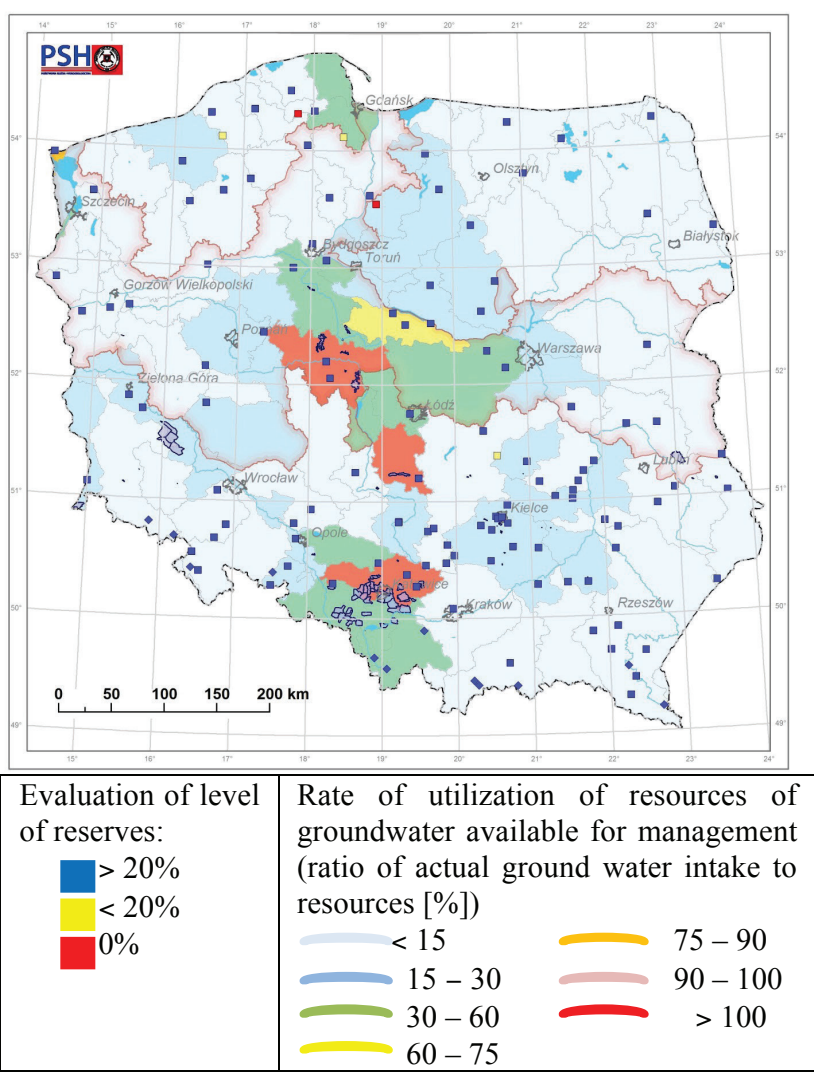

Fig. 2. Rate of utilization of ground water resources in Poland (data for February 2017) [26].

\subsection{Waste management}

The basic legislative act concerning the management of extractive waste is the Act as of $10^{\text {th }}$ of July 2008 on extractive waste (Journal of Laws No 138, item 865) [28] which transposes the provisions of the Directive 2006/21/WE [29] into the national legislation.

The primary objective of the act is the prevention of waste generation in the extractive industry and reduction of the adverse impact of waste on people and the environment. Those assumptions are supposed to be executed through the implementation of:

- rules of management of extractive wastes,

- rules of administration of facility for neutralizing extractive wastes,

- procedures related with obtaining permits and licenses connected with the extractive waste management,

- procedures related with the prevention of major functional failure in waste neutralization facilities of the category A.

According to the act, the stage of extractive waste management commences at the phase of planning of mining activities - so at the stage of design of the method of mineral extraction. Environmental aspects have become the crucial issue in the extractive waste management and they are the very key condition determining the selection of recovery process. Technological and economic issues ceased to be the priority [29]. The research on characteristics of the extractive waste is conducted on the basis of regulation of the Minister for the Environment of the $30^{\text {th }}$ of June 2013 on characteristics of the extractive waste (Journal of Laws 2013 item 759) [30]. The detailed scope of characteristics is presented in the appendix to the regulation. Outcomes of the research determine the choice of technology for further management of waste. Details regarding results of the study can be found in publications $[1,5]$.

\subsection{Environmental management}

Proceeding regarding the assessment of influence of planned undertaking on the environment is regulated by the act of the $3^{\text {rd }}$ of October 2008 on providing information on the environment and its protection, contribution of society to the environment protection and environmental impact assessment (Journal of Laws of 2008 item 199, no 1227) [31]. The latest changes of provisions entered into force on the $1^{\text {st }}$ of January 2017. The act transposes the provisions of the European Parliament and Council Directive 2011/92/UE of the $13^{\text {th }}$ of December 2011 [32] on assessment of effects produced by certain private and public undertakings on the environment and the Council Directive 92/43/EWG of the $21^{\text {st }}$ of May 1992 [33] on protection of natural habitats and wild fauna and flora. 
Table 4 The forms of environmental protection in Poland [34]

\begin{tabular}{|l|c|c|c|l|}
\hline Specification & Number of the objects & \multicolumn{2}{|c|}{ Area } & $\begin{array}{l}\text { Rectrictions on hydrocarbon } \\
\text { deposits exploitation }\end{array}$ \\
\cline { 3 - 5 } & & [thousand ha] & $\begin{array}{c}\text { In total area of } \\
\text { the country }\end{array}$ & \\
\hline Natural parks & 23 & 314.5 & 1.0 & $\begin{array}{l}\text { Exploitation of deposits is } \\
\text { not possible }\end{array}$ \\
\hline Nature reserves & 1,469 & 164.2 & 0.5 & $\begin{array}{l}\text { Exploitation of deposits is } \\
\text { not possible }\end{array}$ \\
\hline Landscape parks & 121 & $2,529.0$ & 8.1 & $\begin{array}{l}\text { Exploitation is only } \\
\text { possible after consultation } \\
\text { with the parc authorities, as } \\
\text { such activity should be } \\
\text { taken into account in } \\
\text { managements plans }\end{array}$ \\
\hline $\begin{array}{l}\text { Protected landscape } \\
\text { areas }\end{array}$ & 386 & $6,992.5$ & & $\begin{array}{l}\text { Economic activity is only } \\
\text { slightly limited }\end{array}$ \\
\hline $\begin{array}{l}\text { Natura 2000 areas- } \\
\text { areas of special birs } \\
\text { protection }\end{array}$ & 144 & 557 & 22.4 & $\begin{array}{l}\text { Network does not introduce } \\
\text { bans, protection system if } \\
\text { flexible }\end{array}$ \\
\hline $\begin{array}{l}\text { Natura 2000 areas- } \\
\text { areas of special } \\
\text { habitat protection }\end{array}$ & 823 & & 17.6 & $\begin{array}{l}\text { Network does not introduce } \\
\text { bans, protection system if } \\
\text { flexible }\end{array}$ \\
\hline
\end{tabular}

The act [31] imposes on enterprisers the obligation of submitting reports on the influence of undertaking on the environment made for the needs of issuing a concession, adopting decisions on environmental conditions for realization of undertaking - so-called environmental decisions, influence of operations of a plant on transformation of morphology and landscape in the area of drilling rig and the influence of procedure of fracturing.

According to the article 3.1.8, under the term of environmental impact one should understand proceeding in the field of assessment of influence of planned undertaking on the environment, which includes in particular:

a) verification of report on the influence of undertaking on the environment

b) obtaining opinion and agreements required by the act

c) ensuring that society can participate in the proceeding.

Within the frames of assessment of the influence of undertaking on the environment one determines, analyzes and evaluates (art. 62.1):

1. direct and indirect influence of a given undertaking especially on the environment, human population and health and living conditions, ..., landscape, ..., availability of deposits,

1a. risk of occurrence of major accidents and natural and construction disasters,

2 possibilities and ways of limiting and preventing the negative influence of undertaking on the environment,

3 required range of monitoring;

and (art. 62.2.) one analyzes and assesses the influence of undertaking on the area of Natura 2000.

Exploration, documentation and exploitation of shale gas should be carried out without negative Approximately $32 \%$ of Poland is covered by various forms of protection, which represent a diverse set of measures to protect nature. Within the protected areas, restrictions on exploitations of hydrocarbon deposits depending on the type of area - may occur (Table 4) [34].

In Fig. 3 protected areas in Poland are presented. National parks with their buffer zones are marked in dark-green and landscape parks with their buffer zones are marked in light-green, while areas of Natura 2000 (Birds Directive and Habitats Directive altogether with a surface area of above $500 \mathrm{ha}$ ) are marked in grey.

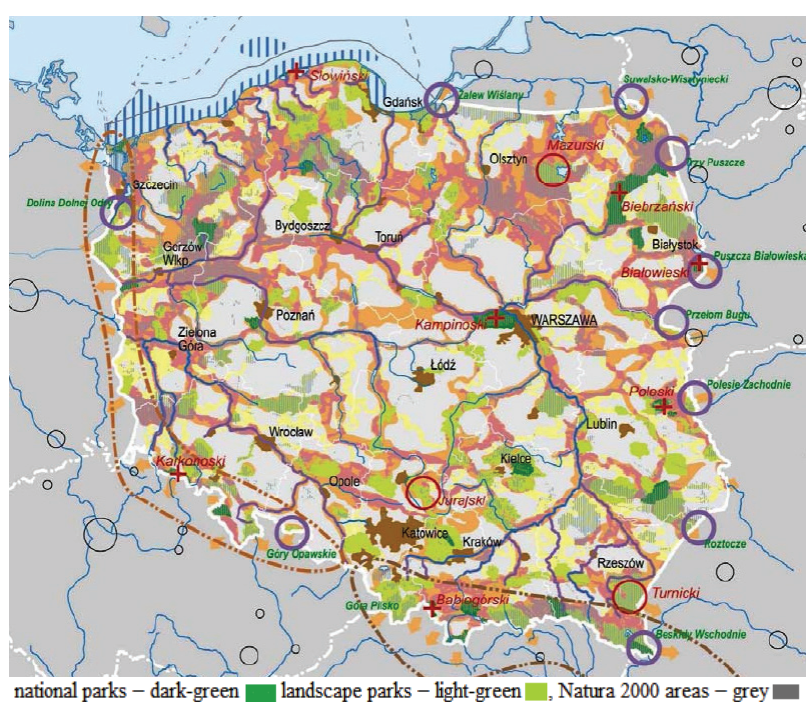

Fig. 3. Protected areas (national parks, landscape parks, Natura 2000 areas) [35]

In Poland all plants carrying out drilling for the purpose of exploration of shale gas deposits are located at a distance of 0,1 to $15 \mathrm{~km}$ from protected areas. Two of them - Lubocino (pomorskie voivodship) and Syczyn (lubelskie voivodship) - are located within the boundaries of area of protected landscape. As it appears 
from the data listed in the study [5], work conducted in those plants can have a potential short-term negative influence on the environment. It particularly concerns: air (connected with the direction of prevailing winds), water (related to the direction of water runoff and its pace) and noise (connected with transportation).

\subsection{Chemical Management}

Issues related with the application of chemical substances in the process of hydraulic fracturing are the subject to legislative actions of the European Union. In accordance with the European Parliament and Council Regulation 1907/2006 of the $18^{\text {th }}$ of December 2006 [36] (with further amendments) - REACH Regulation - there is a legal obligation of registration of chemical substances introduced to the market taking into account all realistic scenarios of exposure. For substances CAS (Chemical Abstracts Service) numbers were defined in order to facilitate their identification. The regulation was implemented to the Polish legislation through provisions of the Act on chemical substances and their mixtures (Journal of Laws of 2015 item 1203 and Journal of Laws of 2016 item 2003) [37].

Because of the potential risk of contamination of the environment with chemical additions used in fracturing, the obligation of showing composition and percentage of all substances used in fracturing fluids by operators was implemented. The detailed composition of fracturing fluid in particular boreholes in Poland is listed on the website of the Polish Exploration and Production Industry Organization [38]. In Table 5 there is a summary of composition of a selected fluid applied in the shale gas exploration in the Lublin region.

Table 5. Hydraulic Fracturing Fluid Composition (Zwierzyniec1) [38]

\begin{tabular}{|c|c|c|}
\hline Ingredients & $\begin{array}{c}\text { Chemical } \\
\text { Abstracts } \\
\text { Service Number } \\
\text { (CAS) }\end{array}$ & $\begin{array}{c}\text { Maximum } \\
\text { Ingredient } \\
\text { Concentration in } \\
\text { Hydraulic } \\
\text { Fracturing Fluid } \\
\text { (\% by mass) }\end{array}$ \\
\hline Water & & $92.44 \%$ \\
\hline Potassium chloride & $7447-40-7$ & $3.330 \%$ \\
\hline Crystalline silica & $14808-60-7$ & $2.039 \%$ \\
\hline $\begin{array}{l}\text { Silica crystalline- } \\
\text { cristobalite }\end{array}$ & $66402-68-4$ & $1.653 \%$ \\
\hline Hydrochloric acid & 7647-01-0 & $0.176 \%$ \\
\hline Polysaccharide & Proprietary & $0.144 \%$ \\
\hline Acetic anhydride & $108-24-7$ & $0.073 \%$ \\
\hline Acetic acid & 64-19-7 & $0.044 \%$ \\
\hline $\begin{array}{l}\text { Proprietary } \\
\text { Component }\end{array}$ & & $0.025 \%$ \\
\hline $\begin{array}{l}\text { Terpenes and } \\
\text { terpenoids, sweet } \\
\text { orange oil }\end{array}$ & $68647-72-3$ & $0.025 \%$ \\
\hline Isopropanol & $67-63-0$ & $0.025 \%$ \\
\hline Modified alkane & - & $0.008 \%$ \\
\hline $\begin{array}{l}\text { Sodium } \\
\text { hypochlorite }\end{array}$ & $7681-52-9$ & $0.008 \%$ \\
\hline Diethylene glycol & $111-46-6$ & $0.007 \%$ \\
\hline Methanol & $67-56-1$ & $0.004 \%$ \\
\hline Sodium hydroxide & $1310-73-2$ & $0.001 \%$ \\
\hline
\end{tabular}

\section{Summary}

Thanks to the technical development it is possible to limit the adverse influence of oil industry on the natural environment. However, one should be fully aware of threats created at all stages of obtaining gas from shale formations.

1. The research conducted in Poland in the area of drilling rig revealed that the activity of the drilling rig influenced the acoustic environment in the immediate vicinity of workshop. The key factor limiting the level of noise pollution is the distance between the location of workshop and residential areas. Results presented in the article showed that emissions of noise from the area of workshop did not affect the excess of valid maximum levels and did not constitute any threat to the comfort of residents.

2. In the article the influence of particular stages of work connected with the exploration of shale gas on the ambient air has been analyzed with respect to the current and compulsory legislation. No excess of $\mathrm{NO}_{\mathrm{x}}$, benzene and BTEX was recorded. Reference values were exceeded for hydrocarbons $-\mathrm{C}_{2}$ to $\mathrm{C}_{12}$ (fracturing and reception of post-treatment fluid). The level for $\mathrm{SO}_{2}$ was also exceeded to a large extent during the fracturing process. The data is presented in Table 2.

3. The problem of potential influence of hydraulic fracturing on groundwater is frequently examined. The research to-date conducted in Poland does not show that crevices resultant during procedures of hydraulic fracturing may reach the zone of groundwater both in the Pomerania and Lubelskie region.

4. Another danger, to which the attention of many researchers is attached, can be the excessive intake of water used in treatments related with fracturing. From the data presented in Table 3 it appears that the utilization of resources of ground waters in the areas of shale gas exploration ranges from 6 to $36,7 \%$. Therefore, at the present stage of exploration work there is no threat of depletion of those resources for other users.

5. Shale gas exploration areas in Poland are located at a relatively long distance from legally-protected areas. Only two of them - Lubocino (Pomeranian voivodeship) and Syczyn (Lublin voivodeship) are situated within boundaries of a protected landscape area. The negative influence of exploration facilities on protected areas can be of short-term character connected with emissions of gases and noise.

The analysis of issue presented in the paper concerns the phase of exploration and identification of gas from shale formations currently realized in Poland. In case of the deposit exploitation phase it is going to vary in the scale of venture. It pertains to the water and waste management in particular.

The work is financed within the frames of statutory research no 11.11.210.373 at the Faculty of Energy and Fuels. 


\section{References}

1. J. Pyssa, E3S Web of Conferences 10, 00076 (2016)

2. http://infolupki.pgi.gov.pl/pl/stan-pracposzukiwawczych/aktualnosci/stan-pracposzukiwawczych-za-gazem-z-lupkow-w-polscemarzec-0

3. EIA/ARI World Shale Gas and Shale Oil Resource Assessment (Advanced Resources International, Inc. June, 2013)

4. http://infolupki.pgi.gov.pl/pl/mapy-koncesji-shalegas

5. The environmental and shale gas exploration. Results of studies on the soil-water environment, ambient air, acoustic climate, process fluids and wastes. (Directorate General for Environment Protection, Warsaw 2015)

6. J. Macuda, Prz. Geol. 58, 266-270 (2010)

7. PGI-NRI, Environmental impact of hydraulic fracturing treatment performed on Eubień LE-2H well. Final Report (Warsaw, November 2011).

8. Modern Shale Gas Development in the United States. A Primer (U.S. Department of Energy. Office of Fossil Energy. National Energy Technology Laboratory, 2009)

9. D. Pakuła, Medycyna Pracy, 66(1), 99-117 (2015)

10. Regulation of the Minister for the Environment of the $26^{\text {th }}$ of January 2010 on reference values for certain substances in the air (J. Laws of 2010, no 16, item 87)

11. Regulation of the Minister for the Environment of the $20^{\text {th }}$ of August 2012 on levels of certain substances in the air (Journal of Laws of 2012, item 1031)

12. T. Steliga, M. Uliasz, Nafta-Gaz, 5, 273-283 (2012)

13. J. Macuda, A. Starzycka, Zeszyty Naukowe IGSMiE PAN, 85, 259-271 (2013)

14. L. Torres, O.P. Yadav, E. Khana, Sci. Total Environ. 539, 478-493, (2016)

15. D. Zhang, T. Yang, Petrol. Explor. Develop. 42(6), 876-883, (2015)

16. W. Orem, C. Tabu, M. Varonka, H. Lerch, A. Bates, M. Engle, L. Crosby, J. McIntosh, International J. Coal Geology, 126, 20-31 (2014)

17. S. L. Brantley, D. Yoxtheimer, S. Arjmand, P. Grieve, R. Vidic, J. Pollak, G. T. Llewellyn, J. Abad, C. Simon, Int. J. Coal Geology, 126, 140$156(2014)$

18. https://www.pgi.gov.pl/logowanie-0/docmandokumenty-pig-pib/docman/psh/zadaniapsh/jcwpd/jcwpd-1-19/4543-karta-informacyjnajcwpd-nr-11/file.html

19. https:/www.pgi.gov.pl/logowanie-0/docmandokumenty-pig-pib/docman/psh/zadaniapsh/jcwpd/jcwpd-1-19/4505-karta-informacyjnajcwpd-nr-13/file.html

20. https://www.pgi.gov.pl/logowanie-0/docmandokumenty-pig-pib/docman/psh/zadaniapsh/jcwpd/jcwpd-1-19/4494-karta-informacyjnajcwpd-nr-19/file.html
21. https://www.pgi.gov.pl/logowanie-0/docmandokumenty-pig-pib/docman/psh/zadania$\mathrm{psh} /$ jcwpd/jcwpd-20-39/4444-karta-informacyjnajcwpd-nr-28/file.html

22. https://www.pgi.gov.pl/logowanie-0/docmandokumenty-pig-pib/docman/psh/zadania$\mathrm{psh} /$ jcwpd/jcwpd-80-99/4401-karta-informacyjnajcwpd-nr-90/file.html

23. European Parliament and Council Directive $2000 / 60 / \mathrm{WE}$ of the $23^{\text {rd }}$ of October 2000 establishing frames for community action in the area of water policy

24. Water Law (J. Laws of 2016, item 352, 1250 and 1948)

25. European Parliament and Council Directive 2006/118/WE of the $12^{\text {th }}$ of December 2006 on protection of ground water against pollution and status deterioration

26. http://www.pgi.gov.pl/psh/psh-2/aktualna-sytuacjahydrogeologiczna/4714-komunikat-o-biezacejsytuacji-hydrogeologicznej-w-okresie-01-02-201728-02-2017/file.html

27. Act as of $10^{\text {th }}$ of July 2008 on extractive waste (J. Laws No 138, item 865) and (J. Laws 2016, item 1579)

28. European Parliament and Council Directive $2006 / 21 / \mathrm{WE}$ of the $15^{\text {th }}$ of March 2006 on management of waste deriving from extractive industry

29. Pyssa J., E3S Web of Conferences 14, 02024 (2017)

30. Regulation of the Minister for the Environment of the $20^{\text {th }}$ of June 2013 on characteristics of extractive waste (J. Laws of 2013, item 759)

31. Act of the $3^{\text {rd }}$ of October 2008 on providing information on the environment and its protection, contribution of society to the environment protection and environmental impact assessment ( $\mathrm{J}$. Laws of 2008 item 199, no 1227) (uniform text Journal of Laws of 2016, items 353, 831, 961, 1250, 1579, 2003)

32. European Parliament and Council Directive $2011 / 92 /$ UE of the $13^{\text {th }}$ of December 2011 on assessment of effects produced by certain private and public undertakings on the environment

33. Council Directive $92 / 43 / E W G$ of the $21^{\text {st }}$ of May 1992 on protection of natural habitats and wild fauna and flora

34. B. Uliasz-Misiak, A. Przybycin, B. Winid, Energy Policy 65, 68-77 (2014)

35. Monitor Polski - Official Gazette, (2012, item 252),

36. European Parliament and Council Regulation (WE) $1907 / 2006$ of the $18^{\text {th }}$ December 2006 on registration, evaluation and granting authorization and applied limitations in the field of chemicals (REACH).

37. Act of the $25^{\text {th }}$ of February 2011 on chemical substances and their mixtures (Journal of Laws of 2015 item 1203 and Journal of Laws of 2016 item 2003)

38. http://www.opppw.pl/en/fracturing fluid compositio $\underline{\mathrm{n} / 23}$ 